\title{
SENIOR'S LIFESTYLE AND THEIR STORE CHOICE
}

To attract and retain customers, an understanding of their motives and reasons for selecting particular food and grocery store is needed. This is of particular importance in the growing segment of seniors. The size of the senior's market demands a better understanding of the older consumer. The aim of our study is to identify psychographic characteristics of the elderly consumer, and to indicate the lifestyle groups and the relationship between these groups and retail store attributes. Differences in the motives for patronizing specific food stores are analyzed for lifestyle groups. We use the lifestyle as a segmentation variable in the diverse population of seniors for the reason, that the lifestyle of the elderly provides more valuable information than chronological age alone. This information can be used by retailers to improve marketing strategies in order to appeal to a target group of senior shoppers. Empirical research is based on a self-administrated questionnaire aimed on the identification of the lifestyle characteristics and retail store attributes of the consumers in $65+$ age, used for the choice of food purchasing retail stores. Lifestyles characteristics were measured by the respondents activities, interests and opinions (AIO). The results of the research indicate that there are differences among the lifestyle groups with significant differences in attitudes towards quality of products or internal store environment. Our research demonstrates the value of psychographic information over age alone regarding the patronage factors in store selection. Our study is a part of the research project VEGA 1/0612/12 „Determinants of the size, structure and tendences in the individual consumption of seniors"

Key words: seniors, segmentation, psychographics, lifestyle classification, grocery store choice

\section{The role of psychograpics and lifestyle in market segmentation}

Customer segmentation is one of the most important concepts in marketing. Customer segmentation can be divided into four distinct types according to the different criteria used in segmenting the population: socioeconomic, geographic, product-related and psychographic. Socioeconomic segmentation focus on the

Prof. ing.Dagmar Lesakova, PhD, University of Economics in Bratislava, Slovak Republic, e-mail: dagmar.lesakova@euba.sk 
customers physical attributes, such as age, sex, income, education, occupation, etc. Geographic segmentation emphasizes the place where customers live. Product-related segmentation classifies customers focusing on their purchase behavior within the relevant product category or the benefits, which the customer expects from a product category. Finally, psychographic segmentation, which is sometimes called also lifestyle segmentation, divides the total population into groups based on the customers motivation, attitudes, preference and values.

Psychographics is a term first introduced by Demby (1974), which brings together "psychology" and „demographics“. He emphasized psychological aspects in order to enhance understanding of consumer behaviour and to develop more effective marketing strategies. Demographic segmentations provide relatively hollow classifications of customers, which reveal nothing about the motives underlying their consumption decisions.

The first wave of psychographic research was mainly rooted in personality profiles. However, this research accompanied with low and even inconsistent correlations with consumer behaviour, was dissapointing and failed to satisfy marketer's needs. One of the main reasons probably was due to the fact that this research used standardized personality tests originally developed in clinical medical diagnostics, or academic - mainly students population - context (Gunter and Furnham, 1992).

In a second wave of psychographic research, the personality concept was replaced with the concept of „lifestyle“. Today, lifestyle is usually defined as the patterns in which people live and spend their time and money. Chaney (1996) defines lifestyles as patterns of action that differentiate people. He writes „lifestyles help to make sense of what people do, and why they do it, and what doing it means to them and others". Today, the lifestyle concept has become so central, and the personality concept so marginal to psychographic research, that the latter is currently equated with lifestyle research (Kahle and Chiagouris, 1997). In general, lifestyle research is based on extensive surveys. Also here we can distinguish different waves of research.

In the first wave lifestyles were researched using large sets of AIO items. AIO refers to measures of activities, interests and opinions. Peter and Olson (1994) define "lifestyle“ as "the manner in which people conduct their lives, including activities, interests and opinions". Activities are manifested actions (work, hobbies, social events, vacation, entertainment, community, shopping, sport, etc.). Interest in some objects, events or topics (family, home, job, community, recreation, fashion, food, media, achievements, etc.) is the degree of excitement that accompanies both special and continuing attention to it. Finally, opinions are descriptive beliefs (of oneself, social issues, politics, business, economics, education, products, culture, etc.) (Plummer, 1974).

Often very large sets of AIO statements were used. For example Cosmas (1982) used a questionnaire containing 250 AIO statements. 
In a second wave of research the AIO framework was replaced by value concept. Values are commonly defined as desirable, trans-situational goals, varying in importance, that serve as guiding principles in people's lives. The most important instrument for measuring values is the Rokeach Value Survey (Rokeach, 1973). His inventory comprises 18 values like: Family security, Freedom, Happiness, Inner harmony, Pleasure, Self-respect, Social recognition, etc.

A shorter and more easily implemented instrument is the List of Values (LOV), suggested by Kahle (1983), including only nine values. Another important scale for assessing value systems was developed by Schwartz (1992).

Now values are of particular interest because values may affect a wide spectrum of behaviour across many situations. Therefore values are also important lifestyle determinants. As Gunter and Furnham (1992) point out: "Lifestyles are defined as patterns in which people live and spend their time and money. They are primarily functions of consumer's values".

Values are broader in scope than attitudes or the types of variables contained in AIO measures. Value inventories in general often only contain a shorter set of values, instead of 200 or 300 AIO items. This led researchers of the second wave of lifestyle research to use value sets as input for their questionnaires, which proved to be much more elegant and fundamental than the AIO approach.

In general, by combining psychographic information with demographics, the marketer will understand better the wants and needs of the consumer. Firms that wish to sell their products and services to the seniors, should use lifestyle variables in segmenting the market. According to Gollub and Javitz (1989), psychology, socioeconomics, and health are the kyes to understanding how seniors can live. Greco (1986) states, that many retailers and manufacturers seem to think that age alone dictates buying pattern and purchasing behavior. However, proper identification of segments which exist within seniors market will allow the development of more effective marketing strategies for serving the seniors. Moschis (2004) indicates that the buying behavior, desires, and needs of the older people must be unique. If uniqueness is lacking, then older consumers are not a distinctive market.

The aim of our paper is to identify lifestyle characteristics of the older consumers and based on these findings to determine distinct lifestyle groups. We intend to find the relationship between the lifestyle groups and the perception of retail store attributes. Differences in the motives for patronizing specific food stores are analyzed for each identified lifestyle group. The research question addressed in our paper is: How do the lifestyles of the older people affect their perceptions of the attributes of retail stores which sell food. 


\section{Retail store attributes and shopping experience}

It was documented in the marketing literature that seniors put special emphasis on retail store attributes when selecting a store for purchase (Moschis et al., 2004). Previous research of older consumers has brought some unambiguous results, concerning the factors influencing their buying behaviour. Some authors (Lumpkin et al., 1985) found that the older people base their store choice on the same attributes as younger people. Other studies of senior shoppers have suggested that there are segments of older people which can be described by unique shopping preferences (Moschis, 2003). We intend to reveal such preferencies and to explore their weight.

The shopping patterns of the elderly support the perception that the elderly posses store loyalty (Moschis, 1997). The elderly do not change their store patronage just to try something different. Price and price-related aspects are of highest importance, which can explain the preference for discount stores and supermarkets with lower price-levels by seniors.

Several studies found that seniors enjoy shopping as an opportunity for social contacts. Lumpkin's study (1988) contradicts these studies. He did not find that the seniors look for interpersonal exchanges with the store personnel. Lumpkin et al. (1985) agree that the most important attributes of store selection relate to the relationship of quality to price and finding of satisfactory products. The senior shoppers want quality products, yet to attractive prices.

The belief among marketers that older consumers are unwilling to try new products is widespread, but the evidence is mixed. Although there is some evidence associating older consumers with a slight tendency to brand loyalty (Lesakova, 2013), most research supports the view that the brand choice processes of older people are as vigorous as those of the young people. Innovativeness is not linked to youth, as is commonly thought, but to personality. Consequently, most variation in brand loyalty is not related to age or other demographic differences. Older consumers are prepared to switch if there are clear benefits for them and they can be described as "late adopters".

Another group of attributes which affects the store choice by the elderly consumers are helpful and courteous salespeople and readability of tags or labels on shelves (Moschis, 1997). Purchase decision of seniors is strongly influenced by emotional factors and approach of selling personnel. Hence, in communication with seniors relationship building must precede presentation of product (Hayley, 2008).

Typical marketing literature and sale presentations tend to be linear presentations of benefits and features. Traditional focus on product features and benefits, or other objective information reaches a point of diminishing returns more quickly among older customers. Marketing messages which lack coherent story and deliver information fragments have only a limited potential to be recalled by seniors. However, to attract seniors, „hard facts should be integrated 
into an emotionalizing story line, to gauge the potential emotional quality of the relationship" (Schewe, 1988).

It was documented in the literature that emotion increases with age. This suggests that the best way to deliver objective, emotionally neutral information to older markets is to combine it with emotionally enriched information. This knowledge has enormous potential importance. It proposes that memory deficits ascribed to senior customers may be overcome by adequate stimuli and that older minds can remember items of categorical importance to them as competently as younger minds.

\section{Methodology}

It was suggested above that chronological age is not the most appropriate segmentation variable. Lifestyle or psychographic variables seem to be more useful in identifying distinct categories of senior's buyer behaviour.

A self-administered questionnaire was used to determine the lifestyle segments and the perception of retail store attributes of the seniors in 65+ age, applied in the choice of retail stores for the purchase of food. We included in the questionnaire several psychological, social and experience dimensions and several factors and events describing the seniors social position and life circumstances. To determine the lifestyle segments, we included in the questionnaire 46 statements describing the activities, interests and opinions (AIO) of seniors. Statements used in the lifestyle research were drawn from Lumpkin et al. (1985). A five-point Likert scale was used, with responses ranging from "not at all for me“ (1) to „very much for me“ (5). Factor analysis was used to reduce the number of variables to a smaller number of factors, which were subjected to cluster analysis to identify the different segments. Utilizing factor analysis and cluster assignment, we were able to identify four distinct lifestyle profiles: Active and self-reliant, Family oriented, Passive and insecure and Stubborn sceptics. Our aim was to identify to what extent these lifestyle groups affect buyer perceptions and behaviour and to show the relationship between seniors lifestyle and perception of retail store attributes.

A random sample of 265 seniors aged over 65 was used for the research. Participation in the research required that the respondents are 65 or older, live in homes or in flats, and do their own shopping for personal or family use.

In the second part of the research the importance of of the various store attributes for the lifestyle segments identified in the first part of the research was determined. Various store attributes related to the convenience of the store location, in-store environment, external environment, quality and price policy, etc. have been studied. Lumpkin et al. (1982) suggest that various attributes may be important to a customer when choosing a store. To determine the 
importance of each attribute, a five-point scale ranging from "never“ (1) to "always" (5) was used. To identify problems with questionnaire clarity, the initial questionnaire was pre-tested on 8 seniors and the questionnaire was revised after the pre-test.

The lifestyle data were submitted to a factor analysis which performed a principal components analysis along with a varimax rotation. Eigenvalues of $\geq 1$ were used as the indicator for the extraction of factors. These extracted factors were then submitted to the varclus procedure to determine the four clusters.

To each created cluster was given a name to describe the key characteristics of the respondents in that particular cluster. Table 1 contains the questionnaire statements in each cluster and their respective loadings, indicating the relative importance of each item. The largest of the clusters was Family oriented with 92 respondents accounting for 34,7 percent of the sample. Active and self-reliant segment counted 62 seniors (23,4 percent), Passive and insecure 60 seniors (22,6 percent) and Stubborn sceptics 51 seniors (19,2 percent).

\section{Results and discussion}

The questionnaire was distributed to 226 women and 39 men, all aged over 65, with the majority of respondents being in the age group of 65-74. The principal focus of the research was to determine how the different lifestyles of the older people affect their perceptions of the attributes of retail stores selling food. Totally 46 statements have been presented to respondents.

Table 1 indicates four distinct lifestyle profiles: Active and self-reliant, Family oriented, Passive and insecure, Stubborn sceptics. 
Table 1: Lifestyle segmentation: statements and their loadings

\begin{tabular}{|c|c|c|c|c|c|c|c|}
\hline \multicolumn{2}{|c|}{ Family oriented } & \multicolumn{2}{|c|}{ Active and self-reliant } & \multicolumn{2}{|c|}{ Passive and insecure } & \multicolumn{2}{|c|}{ Stubborn sceptics } \\
\hline $\begin{array}{l}\text { Prefer spending } \\
\text { time with family }\end{array}$ & 0,86 & $\begin{array}{l}\text { Take active part } \\
\text { in community } \\
\text { life }\end{array}$ & 0,71 & $\begin{array}{l}\text { Financially very } \\
\text { concerned }\end{array}$ & 0,83 & $\begin{array}{l}\text { Make no plans } \\
\text { ahead }\end{array}$ & 0,73 \\
\hline $\begin{array}{l}\text { Enjoy to be with } \\
\text { friends }\end{array}$ & 0,81 & $\begin{array}{l}\text { Like to go } \\
\text { to cultural / } \\
\text { sporting events }\end{array}$ & 0,66 & $\begin{array}{l}\text { Prefer to stay at } \\
\text { home }\end{array}$ & 0,70 & Feel often lonely & 0,62 \\
\hline $\begin{array}{l}\text { Like to talk to } \\
\text { other people }\end{array}$ & 0,78 & \begin{tabular}{|l} 
Use to plan my \\
timeschedule \\
even in \\
retirement \\
\end{tabular} & 0,64 & $\begin{array}{l}\text { Spend much } \\
\text { time watching } \\
\text { TV }\end{array}$ & 0,53 & $\begin{array}{l}\text { Affected by } \\
\text { the past and } \\
\text { nostalgia }\end{array}$ & 0,51 \\
\hline $\begin{array}{l}\text { Feel pride of } \\
\text { things I have } \\
\text { made /built } \\
\text { during my life } \\
\end{array}$ & 0,67 & $\begin{array}{l}\text { Interested in } \\
\text { politics }\end{array}$ & 0,54 & $\begin{array}{l}\text { Fashion dress is } \\
\text { not important } \\
\text { for seniors }\end{array}$ & 0,49 & $\begin{array}{l}\text { Used to } \\
\text { complain }\end{array}$ & 0,49 \\
\hline Enjoy going out & 0,54 & $\begin{array}{l}\text { Enjoy listening } \\
\text { to radio }\end{array}$ & 0,46 & $\begin{array}{l}\text { Low market- } \\
\text { place knowledge }\end{array}$ & 0,46 & $\begin{array}{l}\text { Highly price- } \\
\text { conscious }\end{array}$ & 0,42 \\
\hline $\begin{array}{l}\text { Reed the } \\
\text { newspaper daily }\end{array}$ & 0,45 & $\begin{array}{l}\text { Enjoy reading } \\
\text { magazines }\end{array}$ & 0,42 & $\begin{array}{l}\text { Positive towards } \\
\text { marketing and } \\
\text { advertising }\end{array}$ & 0,45 & $\begin{array}{l}\text { All in life is } \\
\text { predicted }\end{array}$ & 0,40 \\
\hline $\begin{array}{l}\text { Carefull to eat } \\
\text { the healthy food }\end{array}$ & 0,42 & $\begin{array}{l}\text { Able to manage } \\
\text { my household } \\
\text { budget }\end{array}$ & 0,40 & $\begin{array}{l}\text { Fear to go out in } \\
\text { the evenings }\end{array}$ & 0,39 & & \\
\hline & & $\begin{array}{l}\text { Enjoy travelling } \\
\text { in the country }\end{array}$ & 0,38 & & & & \\
\hline
\end{tabular}

Note: Factor loadings $\geq 0,3=$ significant (if sample $\geq 50$ ); Factor loadings $\geq 0,4=$ more important; Factor loadings $\geq 0,5=$ very significant

As demonstrated in Table 2, there are some differences among the lifestyle groups. Family oriented differ significantly from Stubborn sceptics $(\mathrm{p}<0,05)$. The Family oriented seniors consider the attributes of sortiment and quality of products and staff very important in their store choice. There are no significant differences between Family oriented and Active and self-reliant in these attributes; they are equally important to both lifestyle groups. In contrast, Passive and insecure do not find these particular attributes of crucial importance in choosing a retail store.

When considering store characteristics such as fast check-outs, readable tags on shelves, or store location, the research results indicate no significant differences among the groups. 
Table 2: Reasons for patronizing particular food store among older shoppers (65+) by lifestyle segments

\begin{tabular}{|l|l|l|l|l|}
\hline Retail store attributes & $\begin{array}{l}\text { Family } \\
\text { oriented \% }\end{array}$ & $\begin{array}{l}\text { Active and } \\
\text { self-reliant \% }\end{array}$ & $\begin{array}{l}\text { Passive and } \\
\text { insecure \% }\end{array}$ & $\begin{array}{l}\text { Stubborn } \\
\text { sceptics \% }\end{array}$ \\
\hline Lower prices & 84,4 & 84,2 & 92,4 & 88,0 \\
\hline Quality of products & 82,0 & 81,3 & 71,6 & 68,4 \\
\hline Display of products & 44,6 & 39,8 & 47,2 & 49,6 \\
\hline Broad sortiment & 49,8 & 47,6 & 35,6 & 40,2 \\
\hline Fast check-outs & 54,2 & 49,8 & 55,4 & 56,0 \\
\hline Knowledgeable staff & 66,6 & 65,0 & 60,4 & 54,4 \\
\hline Helpful staff & 69,2 & 65,4 & 56,6 & 53,8 \\
\hline Store location close to the seniors home & 81,4 & 76,6 & 80,6 & 80,0 \\
\hline Frequent sales actions and discounts & 82,2 & 80,8 & 90,3 & 86,4 \\
\hline Like discount stores & 76,3 & 79,2 & 88,0 & 84,4 \\
\hline Respondents (total) & 92 & 62 & 60 & 51 \\
\hline Respondents (percent) & 34,7 & 23,4 & 22,6 & 19,2 \\
\hline
\end{tabular}

Source: own calculation

The Active and self-reliant seniors find the knowledge and courteous behaviour of the staff to be important in the selection of a retail store. In contrast, the Stubborn sceptics place little importance on this attribute.

There is no significant variance in the importance placed on lower / reduced prices, however Passive and insecure perceive this factor as most important among all segments.

The lifestyle groups do not find the display of products or broad assortment to be significantly important when selecting retail store. These attributes are not key consideration.

The lifestyle groups differ significantly when considering quality of products, broad assortment or helpful staff. Overall, lifestyle groups do not differ significantly when considering such store characteristics as fast checkouts, readable tags on shelves, or store location and price policy.

While quality of products is an important preference attribute for food store, it is more important to Family oriented ( 82,0 percent) and Active and self-reliant (81,3 percent) than to Passive and insecure (71,6 percent) and Stubborn sceptics $(68,4$ percent). Passive and insecure and to a lesser extent also stubborn sceptics are more likely to prefer food stores because of their prices or discount policy. Family oriented consider whether the grocery stores personnel can assist and advice them, with 66,6 percent and 69,2 percent. 
The Family oriented and Stubborn sceptics differ significantly in their assessment of the quality of products and personnel, with Family oriented placing high importance on both these attributes when selecting a retail store. Also Family oriented and Active and self-reliant differ significantly from the remaining two lifestyle groups regarding quality of products or breath of assortment.

When considering price policy, the Passive and insecure perceive this factor as most important, placing the highest emphasis on it. Also the frequent sales actions and discounts are viewed by this segment as most important.

According to our results, broad assortment and display of products were not seen as important by any of the lifestyle groups.

The research study confirms that age alone does not explain the shopping behaviour of the older people. Lifestyle of the seniors provides more valuable information than chronological age alone. This lifestyle information can be used by retailers to improve marketing strategies in order to appeal to a target group of senior shoppers. It was shown that different lifestyle segments value different retail store attributes.

Based on the findings, some recommendations can be presented. For example, if the store customers are largely Family oriented or Active and selfreliant, the retailer can emphasize quality products and fair prices. It would also be important to hire and train knowledgeable and helpful staff.

If the majority of customers are Passive and insecure or Stubborn sceptics, the store should offer and advertise discounts and lower prices.

\section{Conclusion}

The research presented in the paper indicates that consumer behaviour of seniors not only differ from the consumer behaviour of younger people, but it is also differentiated by psychographic characteristics of seniors consumer segment.

The findings demonstrate the value of psychographic variables and lifestyle in explaining the preference attributes in store selection by seniors. In order to retain the loyalty of Family oriented, food retailers should carry high quality products as well as broad sortiment of products. Senior's households make serious decisions on food purchase, hence it is important also to consider special health needs of this segment (low fat, low sodium, etc.).

Seniors value helpful staff with professional knowledge about the items in the store. Hence, food retailers should train store personnel to be more helpful and courteous.

Because of the seniors physical and health requirements, food stores should pay special attention to the internal store environment, particularly to the display of products, comfortable trolleys, efficient check-outs, etc. The retailers that follow these requirements, are more likely to retain customers and to attract new customers. 
Retailers can benefit from conducting lifestyle analysis of their customers and use that information to adapt their marketing programmes to acquire and retain senior shoppers. Although there are limitations in this research, the findings show the benefits of lifestyle characteristics of the seniors, with psychographic variables supplementing age variable in developing an effective retail strategy.

\section{Literature}

- Cosmas, S.C. (1982): "Life Styles and Consumption Patterns", Journal of Consumer Research, Vol. 8, pp. 453-465.

- Greco, A.J. (1986): “The fashion-conscious elderly: a viable, but neglected market segment”, Journal of Consumer Marketing, Vol. 3, pp. 71-75.

- Gollub, J., Javitz, H. (1989): “Six ways to age”, American Demographics, June, pp. 28-35.

- Gunter, B., Furnham, A. (1992). Consumer Profiles: An Introduction to Psychographics. London : Routledge.

- Hayley, M., Lumbers, M. (2008): "Understanding older shoppers: a phenomenological investigation”, Journal of Consumer Marketing, Vol. 25, pp. 294-301.

- Kahle, L.R., Liu, R., Watkins, H. (1992): "Psychographic Variation across Geographic Regions", Advances in Consumer Research, Vol. 19, pp. 346-352.

- Kaynak, E., Kara, A. (2001): "An Examination of the Relationship among Consumer Lifestyles, Ethnocentrism, Knowledge Structures, Attitudes and Behavioral Tendencies", International Journal of Advertising. Vol. 20 (4), pp. 457-482.

- Lesakova, D. (2013): "Silver consumers and their shopping specifics", Journal of Oeconomia Copernicana 4, Academic Press Toruň, pp . 103-115.

- Lumpkin, J.R. and Hite, R. (1988): "Retailer's offering and elderly consumer needs", Journal of Business Research, Vol. 16, pp. 313-326.

- Lumpkin, J.R. (1985): "Shopping orientation segmentation of the elderly consumer", Journal of Academy of Marketing Science, Vol. 13, pp. 271-289.

- Lumpkin, J.R. and Greenberg, B.A. (1982): "Apparel-shopping patterns of the elderly consumer”, Journal of Retailing, Vol. 58, pp. 68-89.

- Moschis, G., Curasi, C., Bellenger, D. (2004): "Patronage motives of mature consumers in the selcetion of food and grocery stores", Journal of Consumer Marketing, Vol. 21, pp. 123-133.

- Moschis, G. (2003): "Marketing to older adults: an updated overview of present knowledge and practice", Journal of Consumer Marketing, Vol. 20, pp. 516-525.

- $\quad$ Moschis, G., Lee, E., Mathur A. (1997): “Targeting the mature market: opportunities and challenges", Journal of Consumer Marketing. Vol. 14, pp. 14-37. 
- Moschis, G., Curasi, C., Bellenger, D. (2004): "Patronage motives of mature consumers", Journal of Consumer Marketing, Vol. 21, pp. 123-133.

- Oates, B., Shufeldt, L., Vaught B. (1996):"A psychographic study of the elderly and retail store attributes", Journal of Consumer Marketing, Vol. 13, pp. 14-27.

- $\quad$ Peter, J.P., Olson, J.C. (1994): Understanding Consumer Behavior. Burr Ridge, IL: Irwin.

- Plummer, J.T., 1974. “The Concept of Life Style Segmentation”, Journal of Marketing, Vol. 38, pp. 33-37.

- $\quad$ Schewe, Ch.D. (1988): "Marketing to our aging population: responding to physiological changes", Journal of Consumer Marketing, Vol. 5, pp. 61-67.

- Schwartz, S., Bilsky: "Psychographics: A Critical Review", Journal of Marketing Research, Vol. 12, pp 196-213. 
Prof. dr Dagmar Lesakova,

Ekonomski univerzitet u Bratislavi, Republika Slovačka

\section{ŽIVOTNI STIL STARIJE POPULACIJE I NJIHOV IZBOR TRGOVINA HRANE}

\section{S a ž e $\mathbf{t}$ a $k$}

Privlačenje i sadržavanje kupaca, kao i razumevanje njihovih motiva i razloga za odabir određene trgovine hrane su neophodni. Ovo je od posebnog značaja kod sve većeg segmenta starije populacije. Veličina tržišta starije populacije zahteva bolje razumevanje starijeg potrošača. Naše istraživanje ima za cilj da identifikuje psihografske karakteristike starijih potrošača, kao i da ukaže na grupe životnih stilova i odnos između ovih grupa i atributa maloprodajnih objekta. Za grupe životnih stilova analizirane su razlike u motivima za posećivanje određenih trgovina hrane. Životni stil se koristi kao segmentaciona promenljiva u različitoj populaciji starijih iz razloga što životni stil starijih pruža dragocenije informacije nego samo hronološka starost. Trgovci mogu da koriste ove informacije za poboljšanje marketinške strategije kako bi se dopali ciljnoj grupi starijih kupaca. Empirijsko istraživanje se zasniva na upitniku čiji je cilj da identifikuje karakteristike životnog stila i atribute potrošača maloprodajnih objekta starosne dobi 65+, upotrebljenih za izbor malorpodajnih trgovina. Karakteristike životnih stilova su merene na osnovu aktivnosti ispitanika, njihovih interesovanja i mišljenja (AIM). Rezultati istraživanja pokazuju da postoje razlike među grupama životnih stilova, tj. značajne razlike u stavovima po pitanju kvalitetu proizvoda ili unutrašnjeg okruženja prodavnice. Naše istraživanje pokazuje vrednost psihografskih informacija u vezi sa starosnom dobi, po pitanju faktora koji utiču na izbor prodavnice. Studija je deo istraživačkog projekta VEGA 1/0612/12 pod nazivom:"Determinante veličine, strukture i tendencija lične potrošnje kod starije populacije“

Ključne reči: starija populacija, segmentacija, psihografija, klasifikacija životnih stilova, izbor trgovina hrane 